\title{
Linguistic and normative aspects of oil and gas business terminology
}

\author{
Liliya Z. Samigullina ${ }^{1}$ and Elina F. Samigullina ${ }^{2}$ \\ ${ }^{1}$ Ufa State Petroleum Technological University, Branch of the University in the City of Oktyabrsky, Russian Federation \\ ${ }^{2}$ Kazan State University of Architecture and Engineering, 420043, Russian Federation, Kazan
}

\begin{abstract}
The article is devoted to the study of the regulatory aspects of oil and gas terminology in the light of the current processes of globalization of the world economy, as well as the rapid development of the industry's technological processes and the subsequent increase in the number of terminological units. The inconsistencies in the basic concepts of terminology standardization activities are revealed, called forth by the terms "normalization", "unification", "standardization", in the Russian and international terminology practice. Terminological units are presented taking into account the degree of their normalization. The authors come to the conclusion that standardization and unification of terminologies is important for the process of scientific information exchange optimization, automation tools in information, translation, editorial and publishing activities development.
\end{abstract}

\section{Introduction}

One of the factors influencing the process of scientific information exchange optimization, which is currently experiencing a high level of growth, is the development and further improvement of the language means of information transfer, among which the main role is played by terms - words or phrases that are the unity of the sound form and the correlated concept from the system concepts of a given field of science and technology [1]. The bond between the scientific information exchange expansion and terminology study is due to the fact that many methods of computer science are based on methods of working with language units for special purposes. The introduction of automation tools in information, translation, editorial and publishing activities implies the creation of an effective, appropriate modern level of terminology base development.

\section{Materials and methods}

The study carried out is based on the following hypothesis: in modern conditions scientific knowledge globalization and internationalization, the newest technologies of hydrocarbons recovery and processing interpenetration on the domestic and foreign markets the main tasks of the modern stage of terminology work are: identification and elimination of shortcomings in the terminology used in the documentation; the definition of a rational minimum of terminological systems that is necessary and sufficient to meet the needs of professional communication. A number of works on terminology standardization were studied [2-11].

The material for the study, the main results of which are presented in this article, were the English and the
Russian-language terminology units of oil and gas business fixed in the text of scientific monographs, periodicals, textbooks on oil and gas business, electronic databases by the continuous sampling method [12-16].

\section{Results and discussions}

The vocabulary of any national language is divided into general and special vocabulary. The professional communication process is carried out with the help of special lexical units that are a part of a specialized professional language.

The main lexical unit of language for special purposes is the professional term. Terms are the core of the professional language vocabulary and convey the basic content information. Terminology is a means of special scientific and technical concepts expression, storage and transfer and it is formed depending on the level of the scientific or technical knowledge sphere development to that it serves.

The term in professional discourse performs a number of functions. Traditionally, the function of a term is understood as the role that it performs as a means of designating a special concept. Linguists single out the following main functions of the term: nominative (naming), which V.M. Leichik defines as "the function of fixing of a special knowledge" [17]. With a nominative function, a significative function is associated (defining the means of expressing the concept by language sign means). Except for these functions, the term serves for the purposes of the professional communication implementation (communicative function), the discovery and transfer of new knowledge (cognitive function). In modern conditions scientific knowledge globalization and internationalization, the

* Corresponding author: sliliyaz@mail.ru 
newest technologies of hydrocarbons recovery and processing interpenetration on the domestic and foreign markets, the cognitive function is increasingly coming to the forth.

One of the factors of the scientific and information exchange optimizing is the development and further improvement of the information transfer means, mainly terms, since it is the precisely developed, normalized terminology that is an indispensable tool for the successful development of scientific, educational and production activities.

The increasing information processes automation, the computer electronic application for terminological databases and automated dictionaries creating are impossible without terminological vocabulary standardization and unification, the linguistic problems of terminology studying in every specific knowledge area. This stipulates the need for in-depth study and further development of the methodological aspects of terminology formation.

Ordering, harmonization, unification and standardization are the most important types of terminology work. Ordering can be considered as the most common of these concepts and is referred to the process of putting the terminology into a definite order. In Russian scientific tradition terminology ordering is considered as putting the terminology of a certain industry into a feasible system at all levels using special methodology and models sufficient to create a term as a means of expressing a special concept.

Despite the exceptional importance of the work on terminology ordering, international and national practice lacks the uniformity of terms that designate its individual stages and directions. Thus, in the terminology of France, the terms "standardization", "unification", "normalization" are used as synonymous with some preference given to the last one. In English-speaking countries, they speak mainly about standardization, using the notion of a language standard that does not find exact correspondence with the specialists of other countries.

To harmonize the terminology, its unification is necessary, since "only unified terminology can be proposed for standardization". The concept of "unification" implies bringing the terminology into the system both at the content level and at the logical and linguistic levels. Unification is aimed at one-to-one correspondence between the system of concepts and the terminology system ensuring: every concept should have a corresponding naming it term, and vice versa. The main task of optimization is the search for a convenient compact form of a term that would directly or indirectly reflect the main characteristics of a concept named.

Normalization of terminology implies the singling out the most convenient and preferable variants of terms from professional discourse and specifying the rules according to which they should be formed.

Taking into account the degree of recommended value it is customary in terminology work to distinguish the following types of special units:

1. Standardized terms included into official terminology standards;
2. Recommended terms, given in the less compulsory collections of recommended terms;

3. Preferred terms, recommended by reference dictionaries;

4. Allowable terms, given in the first two types of documents as authorized to use alongside with the main term;

5. Reference terms which are not recommended by reference dictionaries;

6. Not recommended terms, listed as undesirable in the recommended terms handbooks;

7. Inadmissible terms prohibited for use by terminological standards.

The need for modern terminology ordering reflects the practical need for optimal terms functioning in specialized literature (primarily educational, reference, documentary, etc.) and in the oral professional communication sphere.

Russian terminologist V.A. Tatarinov considers harmonization as the type of terminological activity, which is aimed at the harmonization of terms at the national and international levels [18].

In accordance with the main provisions of the scientific and technical terminology standardization methodology, first developed by the Committee on Scientific and Technical Terminology of the USSR Academy of Sciences in 1975, the goal of standardization is "rigorous evaluation, analysis and establishment of unambiguous terms corresponding to the modern level of science and technology, scientific substantiation and systematization of terminology, giving the language of science logical harmony and mathematical clarity".

Alongside with the functional research in the 70's and 80 's in the USSR, the work was carried out to normalize and standardize the scientific and technical terminology. The so-called "normocentric" approach made it possible to formulate the following properties of the "ideal" term:

- accuracy;

- univocity within one terminological system;

- absence of ideographic synonyms;

- lack of emotion (which distinguishes it from professionalism);

- motivation, which is determined by the fact that terms are secondary names;

- nominativeness - the function of designating a special concept, which is realized independently of the context;

- the meaning of the term is formulated as a logical definition;

- systematicity - the property of the term to occupy a certain place in the system of terms, which, in turn, is due to a specific place of a special concept, denoted by a term in a system of special concepts;

- systematic character - the property of reflecting systematicity on the morphological, word-formation and categorical levels.

Russian linguist A.S. Gerd considers the identification of the main tendencies and regularities in the historical development of individual terminologies, the analysis of special texts of different chronological 
periods, the thorough description of modern terminology in summary dictionaries and then the elucidation of the main factors, ways, sources, and specific resources for further ordering and unification of terminological systems, the creation of normative dictionaries and reference books as the main tasks of terminology work [19].

The conceptual meanings of the term equivalents in different languages are not always fully compatible. According to the British BS 6723 Guide to establishment and development of multilingual thesauri, the following types of links between equivalents in different languages are observed (see Table 1.):

Table 1. Levels of equivalence.

\begin{tabular}{|c|c|}
\hline bond type & source language \\
\hline complete equivalence & target language \\
\hline incomplete equivalence & \\
\hline $\begin{array}{c}\text { partial equivalence } \\
\text { equivalence }\end{array}$ \\
\hline non-equivalence
\end{tabular}

As it can be seen from the table, the equivalence types are as:

1. Full equivalence: the meaning of the word and its equivalent in another language almost completely coincide, for example:

$$
\begin{aligned}
& \text { the English language the Russian language } \\
& \text { geology } \\
& \text { геология }
\end{aligned}
$$

2. Incomplete equivalence: the meanings of the words do not coincide, but intersect. In a similar kind of relationship, quasi-synonyms often are often considered as full equivalents, for example:

$$
\begin{array}{cl}
\text { the English language } & \text { the Russian language } \\
\text { environment } & \text { 1) окружающая среда } \\
& \text { 2) охрана } \\
\text { окружающей среды }
\end{array}
$$

3. Partial equivalence: the meaning of one word is wider than the meaning of the other. To partial equivalents we can refer to multi-valued words that coincide in one of several values, their meanings are possible to approximate to full equivalence, or to an equivalence "one-to-many", for example:

$$
\begin{gathered}
\text { the English language the Russian language } \\
\text { duty } \\
\text { пошлина, }
\end{gathered}
$$

where the value of duty in the English language is wider than in the Russian language.

4. One-to-many equivalence: the meaning of one word corresponds to a set of values of several words.

the English language $\quad$ the Russian language
$\begin{aligned} & \text { 1)design } \\ & \text { 2)development }\end{aligned}$

5. Non-equivalent terms include those that denote realities that do not have a lexical designation in the vocabulary of another language, for example:

$$
\begin{aligned}
& \text { the English language } \\
& \text { upstream business }
\end{aligned}
$$

$$
\begin{aligned}
& \text { the Russian language } \\
& \text { звенья нефтяной } \\
& \text { отрасли, занятые } \\
& \text { разведкой и } \\
& \text { разработкой } \\
& \text { нефтяных } \\
& \text { месторождений }
\end{aligned}
$$

A great amount of job on the terminology harmonization was carried out, for example, during the Sakhalin-2 project implementation. The result of the work of the team of translators was the bilingual English-Russian and Russian-English thesaurus of oil and gas industry terms, as well as recommendations were worked out for translators to carry out their professional activities [11].

The compilers of the thesaurus propose, in particular, the following options for the translation of the term development in various contexts (see Table 2.):

Table 2. Translation of the term development in various contexts.

\begin{tabular}{|l|l|}
\hline the English language & the Russian language \\
\hline develop reserves & $\begin{array}{l}\text { осваивать/разрабатьвать } \\
\text { месторождения }\end{array}$ \\
\hline plan of development & $\begin{array}{l}\text { пан освоения } \\
\text { месторождений }\end{array}$ \\
\hline full-field development & полномаситабное освоение \\
\hline development engineer & $\begin{array}{l}\text { инженер-разработчик } \\
\text { пласта }\end{array}$ \\
\hline development well & $\begin{array}{l}\text { экслуатационная } \\
\text { скважина }\end{array}$ \\
\hline development drilling & эксплуатационное бурение \\
\hline
\end{tabular}

The terms "develop" and "development" often poses a problem in translation due to their wide semantics. They often come in sustainable combinations (see Table 3):

Table 3. Translation of the terms develop, development in various contexts.

\begin{tabular}{|l|l|}
\hline \multicolumn{1}{|c|}{ the Russian language } & \multicolumn{1}{c|}{ the English language } \\
\hline разработка заводнением & waterflooding \\
\hline разработка на истощение & depletion drive \\
\hline разработать проект & design a project \\
\hline разработать документ & produce a document \\
\hline $\begin{array}{l}\text { разработать проект } \\
\text { постановления }\end{array}$ & draft an executive order \\
\hline
\end{tabular}


The discovery of gas-condensate deposits in the Soviet Union in the middle of the XX century, which differed from oil and gas fields in the development techniques, operation and research, led to the formation of a new direction in scientific research. For these purposes, in 1953, VNIIGAZ organized a gas condensate laboratory, which needed to solve numerous and diverse issues related to gas condensate fields. The first gas condensate terms were adapted terms of oil industry.

Due to the large territorial, informational and educational disunity that was at that time in the USSR, and the need to describe the processes studied in the course of scientific and industrial research, a terminology began to take shape in these regions. So, for example, in various regions synonyms arose for the term "raw condensate" - "saturated condensate", "unstable condensate", for the term "stable condensate" "degassed condensate", "reservoir condensate", "weathered condensate". With the need to standardize all gas-condensate recovery techniques, it was necessary to standardize the terminology.

The terminology standards creation consists of the following stages:

- the specific subject area terminology study with a view to determining the actual use of terminology;

- development of a system of concepts and a system of terms corresponding to them - a logical system of knowledge within the framework of the given subject area;

- the official commissioning of a system of terms by an authoritative group of experts having high competence in this field of science or industry, having the corresponding rights as the organization of standards.

The final stage of terms ordering in the terminology system is its compilation in the form of a standard dictionary. The various kinds of dictionaries creation is an important work in the field of terminology and its more particular branch - terminography, which is aimed at the multi-purpose databases serving as an information resource formation and as a tool for a specific terminology field presentation, and, consequently, for clarifying the object-terms characteristics from the point of view of their position in the terminology system, taking into account their national cultural specifics.

\section{Conclusions}

Thus, the main tasks of the modern stage of terminology work are: identification and elimination of shortcomings in the terminology used in the documentation; the definition of a rational minimum of terminological systems that is necessary and sufficient to meet the needs of professional communication; fixation of terminological units in terminology systems of the modern level of professional and scientific knowledge.

Standards developed by the International Organization for Standardization (ISO) for oil and gas business are, for example:

ISO 1998-1:1998 Petroleum industry - Terminology - Part 1: Raw materials and products
ISO 1998-2:1998 Petroleum industry - Terminology - Part 2: Properties and tests.

ISO 1998-3:1998 Petroleum industry - Terminology

- Part 3: Exploration and production.

ISO 1998-4:1998 Petroleum industry - Terminology - Part 4: Refining.

ISO 1998-5:1998 Petroleum industry - Terminology - Part 5: Transport, storage, distribution.

ISO 1998-6:2000 Petroleum industry - Terminology - Part 6: Measurement.

ISO 1998-7:1998 Petroleum industry - Terminology - Part 7: Miscellaneous terms.

ISO 1998-99:2000 Petroleum industry Terminology - Part 99: General and index.

\section{References}

1. Ya. A. Klimovitsky, Some issues of development and methodology of terminology in the USSR, Rotaprint. CSTT of the USSR Academy of Sciences, (1967).

2. A. Campo, The Reception of Eugen Wuester's Work and the Development of Terminology (Doctoral dissertation, Universite de Montreal (Canada)). (2012)

3. C. Galinski \& W. Nedobity, Special languages, terminology planning and standardization. Standardization of Technical Terminology: Principles and Practices (Second Volume). ASTM International, (1988)

4. C. Galinski \& W. Nedobity, International terminology standardization, Document Infoterm, 1 (1989)

5. S. Pavel, Canadian Terminology Standards in Information Technology, In Standardizing Terminology for Better Communication: Practice, Applied Theory, and Results. ASTM International (1993)

6. S. E. Wright, \& G. Budin, (Eds.). Handbook of terminology management: application-oriented terminology management (Vol. 2). John Benjamins Publishing (2001).

7. Kiš Žuvela, S., \& Ostroški Anić, A. Terminology planning and standardization of basic Croatian musical terminology, Rasprave: C̆asopis Instituta za hrvatski jezik i jezikoslovlje, 43(1), 67-78 (2017)

8. V. E. Starzhinsky, E. V. Shalobaev, M. M. Kane, \& V. I. Goldfarb, Activities of Russian-Speaking Scientists in Development of MMS Terminology, New Advances in Mechanisms, Mechanical Transmissions and Robotics pp. 209-216, Springer, Cham (2017)

9. E. Lövestam, Y. Orrevall, A. Koochek, \& A. Andersson, Health Sociology Review, 25(3), 240255 (2016)

10. M. Antonova, m., \& V. Leichik, Functions of scientific and technical terminology and its application in information processe, Nauchnotekhnicheskaya informatsiya Seriya 2- 
Informatsionnye protsessy i sistemy, (11), 2-8. (1990).

11. L. Kostyukova, V.Leichik, \& Z. Petrova, Problems of terminology coordination of information-retrieval thesauruses and standards on terms and definitions, Nauchno-tekhnicheskaya informatsiya seriya 1organizatsiya i metodika informatsionnoi raboty, (3), 26-29. (1984).

12. M.V. Goryunova, L.S. Kuleshova and A.I. Khakimova, Application of signal analysis for diagnostics, International Conference on Industrial Engineering, Applications and Manufacturing (ICIEAM) (Saint Petersburg, 16-19 May 2017) / the team of authors. - SPb.: IEEE, 2017. - DOI: 10.1109/ICIEAM.2017.8076487

13. V.V. Mukhametshin, Eliminating uncertainties in solving bottom hole zone stimulation tasks, Bulletin of the Tomsk Polytechnic University. Geo Assets Engineering, 328 (7), 40-50, (2017)

14. K.T. Tyncherov, V.Sh. Mukhametshin and L.B. Khuzina, Method to Control and Correct Telemetry Well Information in the Basis of Residue Number System, J Fundam Appl Sci., vol. 9(2S), pp. 13701374, 2017. DOI: 10.4314/jfas.v9i2s.848.

15. V.V. Sergeev, N.G. Belenkova, Yu.V. Zeigman, \& V.Sh. Mukhametshin, Physical properties of emulsion systems with $\mathrm{SiO}_{2}$ nanoparticles. Nanotehnologii $v$ stroitel'stve $=$ Nanotechnologies in Construction, 9(6), 37-64 (2017), DOI: 10.15828/2075-8545-2017-9-6-37-64.

16. M. Ya. Khabibullin, R. I.Suleimanov, D. I. Sidorkin \& I. G. Arslanov, Chemical and Petroleum Engineering, 53(5-6), 378-384. (2017)

17. V.M. Leichik, Terminology. Subject, methods, structure. Moscow: "Librocom", 256 p. (2009)

18. V.A. Tatarinov, General terminology study. 528 p. (2006).

19. A. Gerd, Meaning of terminology and scientific knowledges, Nauchno-tekhnicheskaya informatsiya seriya 2-informatsionnye protsessy i sistemy, (10), 1-4, (1991). 